\title{
Magnetic properties and structure of $\mathrm{TiO}_{2}-\mathrm{Mn}(0.73 \%)$ nanopowders: the effects of electron irradiation and vacuum annealing
}

\author{
M. A. Uymin ${ }^{\dagger, 1,2}$, A.S. Minin ${ }^{1,2}$, A. Y. Yermakov ${ }^{1,2}$, A. V. Korolyov ${ }^{1}$, M. Y. Balezin ${ }^{3}$,
} S. Y. Sokovnin ${ }^{2,3}$, A. S. Konev ${ }^{1,2}$, S. F. Konev ${ }^{2}$, L.S. Molochnikov ${ }^{4}$, V.S. Gaviko ${ }^{1}$, A. M. Demin ${ }^{5}$

${ }^{1}$ M. N. Miheev Institute of Metal Physics of Ural Branch of RAS, 18 S. Kovalevskaya St., Yekaterinburg, 620990, Russia

${ }^{2}$ Ural Federal University n. a. the first President of Russia B. N. Yeltsin, 19 Mir St., Yekaterinburg, 620002, Russia ${ }^{3}$ Institute of Electrophysics, Ural Branch of RAS, 106 Amundsena St., Yekaterinburg, 620016, Russia

${ }^{4}$ Ural State Forest Engineering University, 37 Sibirskii tract, Yekaterinburg, 620032, Russia

${ }^{5}$ Postovsky Institute of Organic Synthesis, UB of RAS,

20 S. Kovalevskaya St., Yekaterinburg, 620990, Russia

\section{†uimin@imp.uran.ru}

\begin{abstract}
Nanopowder $\mathrm{TiO}_{2}-0.73 \% \mathrm{Mn}$ was synthesized by the sol-gel method. Thermal treatment of the samples was carried out in vacuum at a temperature of $500^{\circ} \mathrm{C}$. Magnetic properties were studied in the temperature range from 2 to $850 \mathrm{~K}$. The effects of electron irradiation and vacuum annealing on the EPR spectra and magnetic properties of $\mathrm{TiO}_{2}-\mathrm{Mn}$ powder are discussed. It was established that a part of manganese ions in the anatase crystal lattice interacts antiferromagnetically, which causes a decrease in magnetization as compared to the result of the calculation for noninteracting ions. Vacuum annealing leads to the formation of oxygen vacancies and, at the same time, to a noticeable increase in the ferromagnetic contribution to magnetization, especially, after preliminary electron irradiation. We assume that the ferromagnetic contribution to the magnetization appears either due to incomplete compensation of antiferromagnetically directed moments of manganese ions, or due to positive exchange interactions of Mn ions via defects in the $\mathrm{TiO}_{2}$ lattice. It is shown that the temperature of magnetic disordering in samples with a spontaneous magnetic moment exceeds $600^{\circ} \mathrm{C}$.
\end{abstract}

Keywords: $\mathrm{TiO}_{2}-\mathrm{Mn}$ nanopowders, electron beam irradiation, ferromagnetism, EPR.

УДК: 538.955

\section{Магнитные свойства и структура нанопорошков $\mathrm{TiO}_{2}-\mathrm{Mn}(0.73 \%)$ :}

влияние облучения электронами и вакуумного отжига

Уймин М.А. ${ }^{\dagger 1,2}$, Минин А.С. ${ }^{1,2}$, Ермаков А.Е. ${ }^{1,2}$, Королев А. В. ${ }^{1}$, Балезин М.Е. ${ }^{3}$, Соковнин С. Ю. ${ }^{2,3}$, Конев А. С. ${ }^{1,2}$, Конев С. Ф. ${ }^{2}$ Молочников Л. С. ${ }^{4}$ Гавико В. С. ${ }^{1}$, Демин А. М. ${ }^{5}$

†uimin@imp.uran.ru

${ }^{1}$ Институт физики металлов имени М.Н.Михеева Уральского отделения РАН, ул. С.Ковалевской, 18, 620990, Екатеринбург, Россия

²Уральский федеральный университет имени первого Президента России Б. Н. Ельцина, ул.Мира, 19, 620002, Екатеринбург, Россия

${ }^{3}$ Институт электрофизики Уральского отделения РАН, ул. Амундсена, 106, 620016, Екатеринбург, Россия ${ }^{4}$ Уральский государственный лесотехнический университет, Сибирский тракт, 37, 620100, Екатеринбург, Россия ${ }^{5}$ Институт органического синтеза УрО РАН им. И.Я.Постовского, ул. С. Ковалевской, 20, 620990, 
Нанопорошок $\mathrm{TiO}_{2}-0.72$ \% Mn был получены золь-гельным методом из изопропилоксида титана и хлорида марганца. После приготовления и отмывки ксерогель кальцинировался при $300^{\circ} \mathrm{C}$. Размер частиц составил около 4 нм по данным BET. По данным XRD наночастицы имеют структуру анатаза. Были проведены термообработки в вакууме при $500^{\circ} \mathrm{C}$. Изучены магнитные свойства в температурном интервале 2-850 К. В работе обсуждается влияние облучения электронами и вакуумного отжига на ЭПР спектры и магнитные свойства порошка $\mathrm{TiO}_{2}-\mathrm{Mn}$. Было установлено, что часть ионов марганца в кристаллической решетке анатаза взаимодействуют антиферромагнитным образом, в результате чего происходит снижение намагниченности по сравнению с расчётом для невзаимодействующих ионов. ЭПР спектр порошков $\mathrm{TiO}_{2}$-Mn характеризуется наличием широкого сигнала, который обусловлен обменно связанными ионами $\mathrm{Mn}^{2+}$. Эти ЭПР данные хорошо согласуются с результатами магнитных измерений. Вакуумный отжиг приводит к образованию кислородных вакансий и одновременно к заметному росту ферромагнитного вклада в намагниченность особенно после предварительного облучения электронами. Мы предполагаем, что ферромагнитнгый вклад в намагниченность возникает либо из-за неполной компенсации антиферроммагнитно ориентированных моментов ионов марганца (образование скошенных спиновых структур) либо из-за положительных обменных взаимодействий ионов Mn друг с другом через дефекты (вакансии по кислородной подрешетке) в ТіО. помощи высокотемпературных магнитных измерений, что температура магнитного разупорядочения в образцах со спонтанным магнитным моментом превышает $600^{\circ} \mathrm{C}$.

Ключевые слова: нанопорошки $\mathrm{TiO}_{2}-\mathrm{Mn}$, облучение электронами, ферромагнетизм, ЭПР.

\section{Introduction}

Titanium oxides doped with $3 d$-elements have recently been intensively studied, because there still remains uncertainty in understanding the nature of the ferromagnetic state, which as reported, is realized in such compounds synthesized in various ways. A number of conceptions have been suggested to explain the effect. In a remarkable paper [1], several mechanisms are discussed for the appearance of spontaneous magnetic moment in dilute semiconductors doped with $3 d$ metals, based on models of intrinsic nature (for instance, conceptually in the frame of the localized magnetic moments (RKKY interactions between $3 d$-spins, bound magnetic polarons (BMP)) and delocalized electrons (e.g., Stoner ferromagnetism, including Rashba spin-orbit coupling and giant orbital paramagnetism). The emergence of extraneous magnetic phases, which cannot be excluded from consideration as a probable cause of the appearance of the ferromagnetic contribution, is discussed to a lesser extent. These phases are often extremely difficult to detect using traditional diffraction methods, for example, due to the high dispersion of these phases. In [2], the strong influence of the surface contribution to the magnetism of undoped $\mathrm{TiO}_{2}$ nanoparticles due to presence of oxygen vacancies and $\mathrm{Ti}^{3+}$ spins on the surface was proposed. However, it should be noted that the surface is the preferable sink of both defects, such as oxygen vacancies and impurities of $3 d$-metals, which are present in small amounts in the $\mathrm{TiO}_{2}$ matrix. Hence, one cannot completely exclude the formation of foreign magnetic phases on the surface as a result of the accumulation of defects and $3 d$ impurities on the surface.

In fact, even the origin of the experimentally observed ferromagnetic phenomenon is often questioned: what if this ferromagnetic behavior is the result of the presence of phases other than the $\mathrm{TiO}_{2}$-based matrix? This question becomes especially critical when such elements as $\mathrm{Fe}, \mathrm{Ni}$ and $\mathrm{Co}$ are used as dopants, so far as such materials are characterized by a high spontaneous magnetization in the metallic state. This is the main physical reason why manganese is added as a dopant. The situation looks somewhat less complicated: $\mathrm{Mn}$ in the metallic state is proved to be antiferromagnetic, as are its known oxides, except for ferrimagnetic $\mathrm{Mn}_{3} \mathrm{O}_{4}$ that has the Curie point below $100 \mathrm{~K}$. Therefore, when analyzing the magnetic properties of titanium oxide $\mathrm{TiO}_{2}-\mathrm{Mn}$, if there are any manifestations of ferromagnetism at room temperature, they cannot be attributed to the possible existence of manganese-based phases. It has to be admitted that among the large number of studies published on the magnetism of doped titanium oxides, there are not so many published studies on titanium oxides doped with manganese [3-5]. Most of the studies report that the ferromagnetic contribution is comparatively small and amounts to tenths or hundredths of emu/g units. Such a small contribution corresponds to a very low value of the average magnetic moment per manganese atom, which is also as small as on the order of hundredths of Bohr magneton: which is orders of magnitude less than the magnetic moment of the manganese ion with a charge of $2+$ and the spin value of $S=5 / 2$. To our knowledge, the reason for such discrepancy is not practically discussed in the literature; there is no analysis of the paramagnetic contribution into magnetization being provided.

The ferromagnetic state in $\mathrm{TiO}_{2}-\mathrm{Mn}$ compounds, as in other titanium oxides, is most often interpreted using the model of bounded magnetic polarons (BMP). This model assumes the presence of oxygen vacancies as a necessary component. Oxygen vacancies can be created either during synthesis, provided that certain conditions are met, or can be introduced using special heat treatments, most often it is annealing in vacuum. There is also another process known to increase the number of oxygen vacancies: electron irradiation of the sample. In [6], it was reported that due to irradiation of $\mathrm{TiO}_{2}$ powders with an electron beam (at a dose of several MGy), the Ti/O ratio essentially increases as the powder becomes depleted with oxygen ions. With the crystal structure remaining the same, such depletion can only be ensured by an extremely high density of oxygen vacancies.

The purpose of this work is to study changes in the structure and magnetic properties of manganese-doped titanium oxide under the effect of an electron beam and annealing in vacuum. A special attention was paid to the 
features of the magnetization curves plotted for titanium oxide powders in different states by analyzing both the ferromagnetic component and the paramagnetic component of the total magnetization.

\section{Materials and Methods}

Titanium oxide nanoparticles were synthesized by the sol-gel method based on the technique described in [4]. Titanium isopropyl oxide was dissolved in isopropyl alcohol and then a $\mathrm{MnCl}_{2}$ solution acidized with hydrochloric acid to a $\mathrm{pH}$ of 1 was added. The resulting gel was held in a water bath at a temperature of $80^{\circ} \mathrm{C}$ for two hours, after which it was centrifuged out and then rinsed with isopropyl alcohol and water to neutral $\mathrm{pH}$ and dried out.

After synthesis, the powders were annealed in air at $300^{\circ} \mathrm{C}$ for 2 hours to remove the remaining traces of organic contaminants and water. Chemical analysis of the sample revealed that the content of manganese is $0.5 \mathrm{wt} . \%$ (0.73 at.\%). Electron irradiation was carried out using a URT-1M nanosecond electron accelerator [7]. The accelerating voltage was $800 \mathrm{kV}$, and the pulse duration was approximately $90 \mathrm{~ns}$, the cross section of the electron beam was $5 \times 40 \mathrm{~cm}$. The radiation dose was equivalent to $50 \mathrm{MGy}$. Thin layers of powders were scattered and wrapped in aluminum foil with a thickness of 9-10 micron to obtain a pack of $\sim 60 \times 20 \mathrm{~mm}$ in size, and the thickness of the powder layer was no more than a fraction of $\mathrm{mm}$. Annealings were carried out at $500^{\circ} \mathrm{C}$ in an oil-free vacuum of $10^{-4}$ Torr for 0.5 hours. The heat treatment arrangements and marking of the samples are as follows: $S 1-$ annealing at $300^{\circ} \mathrm{C}$ for 2 hours in air; $S 2-$ annealing at $300^{\circ} \mathrm{C}$ for 2 hours in air + annealing at $500^{\circ} \mathrm{C}$ for 0.5 hours in vacuum; $S 3$ - annealing at $300^{\circ} \mathrm{C}$ for 2 hours in air + electron irradiation; $S 4-$ annealing at $300^{\circ} \mathrm{C}$ for 2 hours in air + electron irradiation + annealing at $500^{\circ} \mathrm{C}$ for 0.5 hours in vacuum.

The structure of the powders was investigated using an Empyrean X-ray diffractometer in the filtered copper radiation by scanning with a step of 0.013 degrees. Primary data processing and parameter calculations were carried out using the HighScore Plus 4.1 software package. The

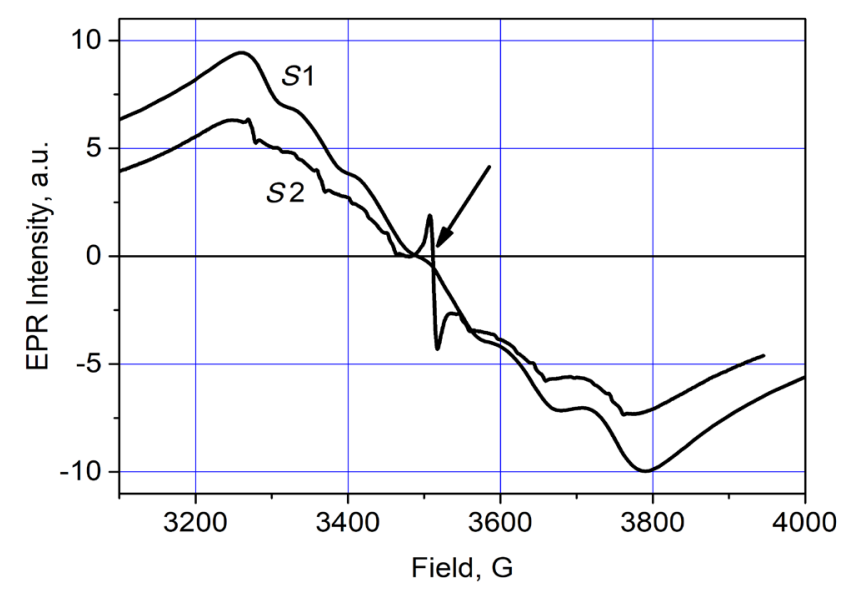

a specific surface was measured using $\mathrm{N}_{2}$ adsorption with a SORBI - M sorptimeter. Magnetic properties were measured using an MPMS-5 SQUID magnetometer in the temperature range from 2 to $300 \mathrm{~K}$. The magnetization curves in the temperature range $300-850 \mathrm{~K}\left(20-580^{\circ} \mathrm{C}\right)$ were measured in Ar atmosphere using Faraday balance.

Measurements of electron paramagnetic resonance (EPR) were performed on a Bruker ELEXSYS 580 pulse spectrometer in the stationary mode. The sample powder was placed in a special quartz tube with a diameter of $4 \mathrm{~mm}$. The sample volume ranged from 2 to $5 \mathrm{~mm}^{3}$. The spectra were recorded in the stationary mode at room temperature with Super High-Q rectangular resonator. The frequency of the microwave field was about $9.40 \mathrm{GHz}$. The interval of change of the magnetic field strength $B$ ranged from 480 to 6000 Oe.

The FTIR spectra were recorded on a Nicolet 6700 FTIR spectrometer (Thermo) by the method of attenuated total reflectance on a diamond crystal in the range of $4000-600 \mathrm{~cm}^{-1}$.

\section{Results}

The X-ray diffraction revealed that the $\mathrm{TiO}_{2}-\mathrm{Mn}$ samples before and after vacuum annealing have the anatase structure (Fig. S1, Supplementary Material). The size of coherent scattering domains, determined from the line broadening, was of the order of $4 \mathrm{~nm}$. The specific surface area was $270 \mathrm{~m}^{2} / \mathrm{g}$, which corresponds to the particle size of the powder, determined from the size of coherent scattering domains. After the electron irradiation, the specific surface area was $290 \mathrm{~m}^{2} / \mathrm{g}$, with the size of coherent scattering domains increasing up to $7 \mathrm{~nm}$. This interesting result appears most probably because during the electron irradiation, heating causes an increase in the particle size, but at the same time there are more defects growing on the particle surface, which results in a nominal growth of the specific surface, despite the growing particle size.

The EPR spectra of powders $S 1-S 4$ are shown in Fig. 1a and $1 \mathrm{~b}$. The spectra mainly contain a sextet attributed to the $\mathrm{Mn}^{2+}$ ions superimposed on a wide spectrum with the $g$-factor 2, having a width of about 500 Oe. This type of

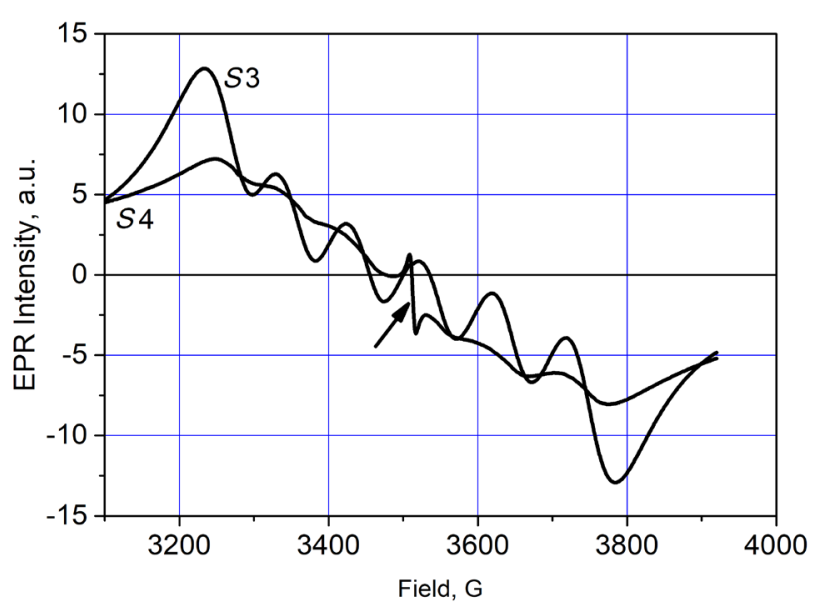

b

Fig. 1. EPR spectra of the samples $S 1$ and $S 2$; the arrow marks the position of the oxygen vacancy line (a). EPR spectra of the samples $S 3$ and S4; the arrow marks the position of the oxygen vacancy line (b). 
spectrum is typical for manganese ions in the octahedral environment of oxygen ions in titanium sites. Presumably, the broadening of this line is caused by the dipole-dipole and, possibly, the exchange interaction between the $\mathrm{Mn}^{2+}$ ions. The spectrum, measured in the field range up to $6000 \mathrm{Oe}$, in fact, demonstrates, in addition to the dipole-dipole broadening, the existence of at least one wide line above 2000 Oe, which can be connected to the Mn atoms involved in the exchange interaction (Fig. S2, Supplementary Material).

It should be noted that after irradiation ( $S 3$, Fig. 1b), the intensity of sextet lines increases significantly from the paramagnetic $\mathrm{Mn}^{2+}$ ions modulating the wide line. During the subsequent vacuum annealing, the intensity of these lines decreases again. At the same time, the wide line becomes less intense. The microscopic nature of this effect is still unclear. The line with $g$-factor 2 , corresponding to oxygen vacancies, appears only after vacuum annealing (samples $S 2$ and $S 4$, the lines are marked with arrows in the Fig. 1a,b). Contrary to expectations, after irradiation (sample S3), no evidences of oxygen vacancies are observed in the EPR spectrum. This may be due to exposure conditions, namely the influence of the air atmosphere. Under the action of an electron beam in the air atmosphere, ozone is formed, which can heal the nucleated vacancies. Oxygen vacancies can also interact with water vapor in the air atmosphere. An increase in the amount of adsorbed water was detected when comparing the IR spectra of samples $S 1$ and $S 3$ (Fig. S3, Supplementary Material).

The magnetization curves plotted for all the samples appear to be linear in the fields ranging from 14 to $30 \mathrm{kOe}$ at temperatures ranging from 80 to $300 \mathrm{~K}$. From these linear functions, the paramagnetic susceptibility was found at each temperature within the range, and then the susceptibility value as a function of inverse temperature was plotted; and some of such dependences are presented in Fig. S4 (Supplementary Material). As can be seen from Fig. S4, irradiation does not affect the magnetic susceptibility of the $\mathrm{TiO}_{2}-\mathrm{Mn}$ powder. All dependences were fitted with the linear functions from the slope of which the Curie constants and effective magnetic moments were determined (Table 1) .

As can be seen from Table 1, the effective magnetic moments of the Mn ion, determined from the magnetic susceptibility data, are somewhat lower than the value $5.9 \mu \mathrm{B}$ characteristic of the $\mathrm{Mn}^{2+}$ ion. Probably, this difference is caused by the presence of antiferromagnetic (AF) interactions between Mn ions, which reduces the magnetic susceptibility

Table 1. Curie constants and effective moments of $\mathrm{Mn}^{2+}$ of different samples.

\begin{tabular}{|c|c|c|}
\hline Sample & $\begin{array}{c}\text { Curie constant, } \\
K \cdot \mathrm{cm}^{3} / \mathrm{g}\end{array}$ & $\begin{array}{c}\text { Effective magnetic } \\
\text { moment, } \mu_{\mathrm{B}}\end{array}$ \\
\hline$S 1$ & $3.56 \cdot 10^{-4}$ & 5.61 \\
\hline$S 2$ & $3.70 \cdot 10^{-4}$ & 5.67 \\
\hline$S 3$ & $3.51 \cdot 10^{-4}$ & 5.55 \\
\hline$S 4$ & $3.31 \cdot 10^{-4}$ & 5.42 \\
\hline
\end{tabular}

and, consequently, the susceptibility-derived moment is also reduced. The same correlations, apparently, lead to a considerable disagreement between the magnetization curves calculated in accordance with the Brillouin function for a temperature of $2 \mathrm{~K}$ and the magnetization curves obtained experimentally (Fig. 2). This disagreement reaches its maximum for the sample $S 4$ subjected to the electron irradiation and annealing; and in this case, even a decrease in the Mn content to 0.35 wt.\% does not yield a satisfactory fitting, because the slope of the curve is much greater in the fields of 20-40 kOe. This slope also indicates the presence of antiferromagnetic interactions between the magnetic moments of the Mn ions. This conclusion agrees well with the EPR study, where one can observe the broadened lines (more than $500 \mathrm{Oe}$ ), which could be attributed to the AF correlations.

Extrapolating the linear part of the magnetization curve onto the zero field at different temperatures, the ferromagnetic contribution into magnetization (FCM) was determined for each sample in the temperature range from 80 to $300 \mathrm{~K}$.

As can be seen from Fig. $3 \mathrm{a}$, annealing in vacuum (samples $S 2$ and S4) results in a strong growth of the FCM, but the absolute value of specific magnetization is not so high in the range from 0.002 to $0.017 \mathrm{emu} / \mathrm{g}$. The FCM practically does not change in value over the temperature range from 80 to $300 \mathrm{~K}$ (Fig. $3 \mathrm{~b}$ ).

The magnetization curves of sample $S 2$ were measured in the temperature range from 20 to $580^{\circ} \mathrm{C}$. Some of these curves are shown in Fig. 4. By extrapolation to zero field, the temperature dependence of the FCM value was determined in the mentioned temperature range. This dependence is presented in Fig. 5. The dependences $M(T)$ for bcc-iron and iron oxide $\mathrm{Fe}_{3} \mathrm{O}_{4}$, taken from the literature, are shown exclusively for comparison. As can be seen from Fig. 5, the temperature dependence of the magnetization does not correspond to either iron or iron oxide. The critical temperature of the disappearance of magnetic order for sample $S 2$ is in the range of $600-700^{\circ} \mathrm{C}$. We do not use the term "Curie temperature" or "Néel temperature", since we do not have data on the type of magnetic order. The total amount of manganese ions involved in this

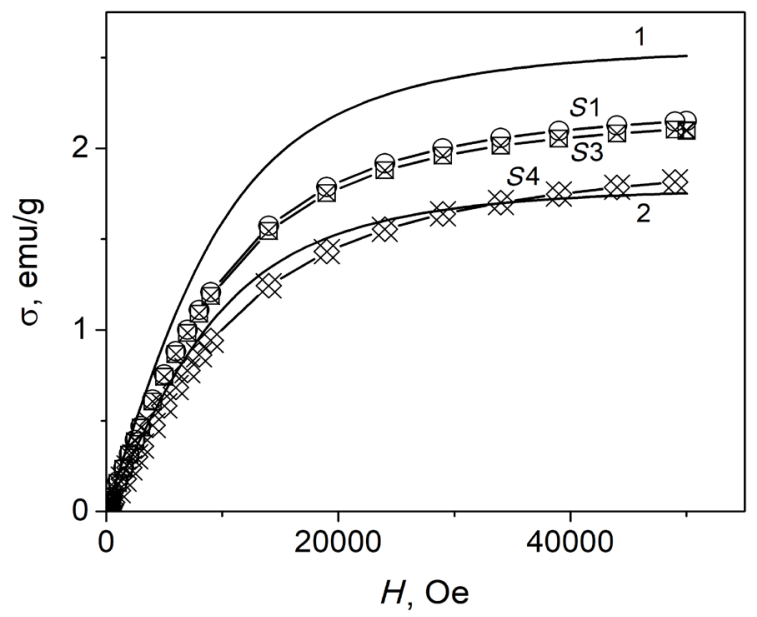

Fig. 2. Field dependencies of specific magnetization of powders $S 1$, $S 3$ and $S 4$ at $2 \mathrm{~K}$. Curves 1 and 2 are the Brillouin function for the spin state of $S=5 / 2$ and $\mathrm{Mn}$ ion content of $0.5 \mathrm{wt} . \%$ and $0.35 \mathrm{wt} . \%$, respectively. 


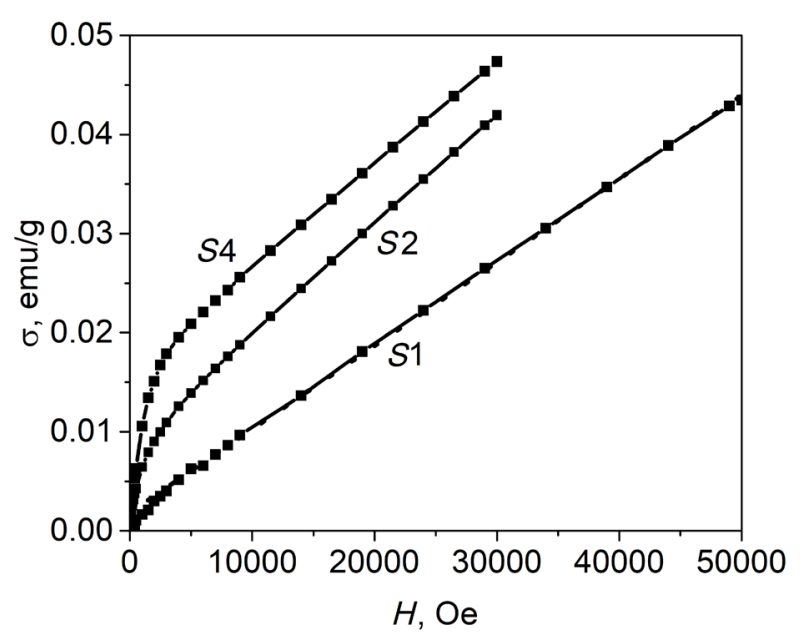

a

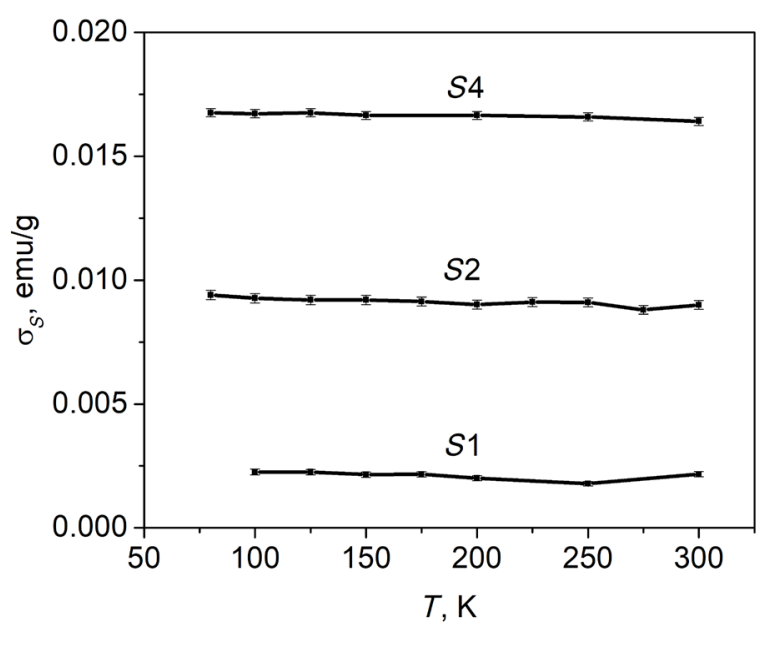

$\mathrm{b}$

Fig. 3. Magnetization curves for $\mathrm{TiO}_{2}-\mathrm{Mn}$ samples $S 1, S 2$ and $S 4$ at $300 \mathrm{~K}$ (a). Temperature dependence of saturation magnetization of the samples $S 1, S 2$ and $S 4(\mathrm{~b})$.

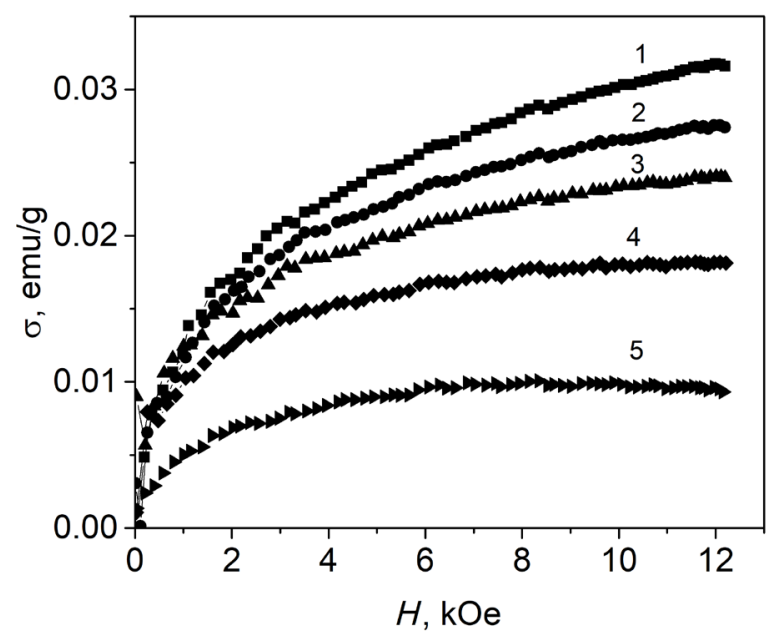

Fig. 4. Magnetization curves of $S 2$ sample at $24^{\circ} \mathrm{C}(1), 100^{\circ} \mathrm{C}(2)$, $200^{\circ} \mathrm{C}(3), 400^{\circ} \mathrm{C}(4)$ and $580^{\circ} \mathrm{C}(5)$.

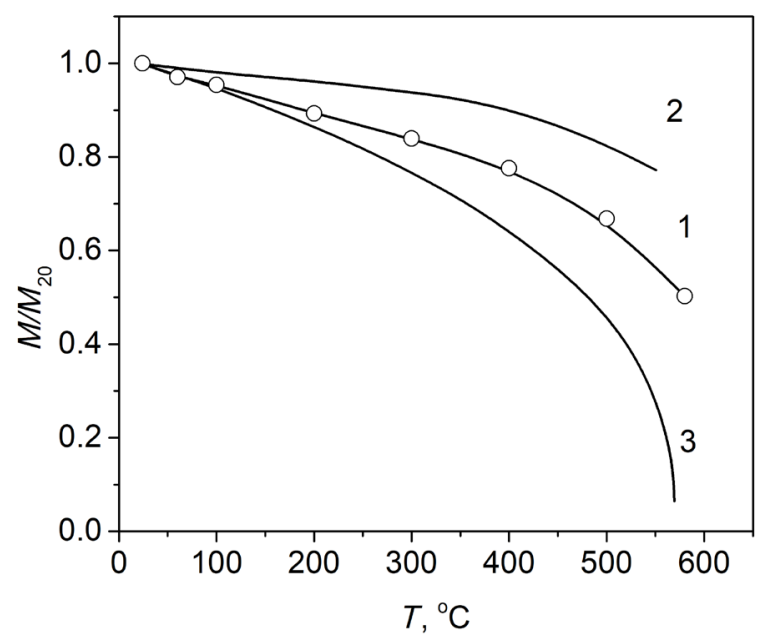

Fig. 5. Temperature dependence of FCM for $S 2$ sample (1) and saturation magnetization for bcc-iron (2) and $\mathrm{Fe}_{3} \mathrm{O}_{4}(3)$. magnetic phase can be estimated from the deviation of the effective magnetic moment from the calculated value for the spin $S=5 / 2$ (Table 1 and Fig. 2). This value ranges from 15 to $30 \%$ of the total number of Mn ions. Based on the value of the ferromagnetic contribution to the magnetization (FCM), the magnitude of the uncompensated moment per manganese atom in this antiferromagnetic phase can be estimated as $0.1 \mu \mathrm{B}$. Thus, the magnetically ordered regions formed during the vacuum annealing of $\mathrm{TiO}_{2}-\mathrm{Mn}$ nanopowders can have antiferromagnetic ordering with incomplete compensation of magnetic moments. The incomplete compensation makes it possible to estimate the temperature of the magnetic disordering by measuring the magnetization curves versus temperature. One can suggest that a paramagnetic state, antiferromagnetic correlations and the regions of AFM interactions with incomplete compensation of magnetic moments can coexist in the sample simultaneously.

Up to now, we do not exclude the another nature of ferromagnetic contribution but it takes a special investigation in the future.

\section{Conclusion}

Analysis of the magnetization curves and the EPR spectra allows us to conclude that, at least for a part of the manganese ions in titanium oxide, there is a negative interaction of exchange nature. It can be assumed that this interaction is a well-known Mn-O-Mn superexchange. Vacuum annealing leads to the appearance of a ferromagnetic contribution to the magnetization. This contribution may be the result, for example, of incomplete compensation of the magnetic moments of manganese in the $\mathrm{TiO}_{2}$ lattice in the presence of oxygen vacancies. Another explanation is that, along with the AF interactions between the Mn ions, the ferromagnetic ordering of the $\mathrm{Mn}$ atoms in the $\mathrm{TiO}_{2}$ lattice near the defects arising during vacuum annealing can occur. Analysis of the temperature dependence of the magnetization demonstrates a sufficiently high temperature of magnetic ordering of about $600-700^{\circ} \mathrm{C}$. The nature of the strong exchange interaction, 
which ensures such a high temperature, is still unclear, and additional studies will be needed in the future to clarify this phenomenon.

Electron irradiation significantly affects the EPR spectrum of manganese ions, increasing the intensity of the lines, but does not lead to the appearance of a signal from oxygen vacancies. Probably, to create and preserve oxygen vacancies, it is necessary to perform the irradiation in an inert gas environment or in a vacuum.

Acknowledgements. The X-ray investigations and magnetic measurements were performed at the Collective Use Test Center of Nanotechnologies and Advanced Materials (IMP UB RAS). IR spectra were measured at the Joint-Use Center for Spectroscopy and Analysis of Organic Compounds of the Postovsky Institute of Organic Synthesis of RAS (Ural Branch). The authors are grateful to S. I. Novikov for carrying out specific surface measurements. The research was carried out within the state assignment (themes "Magnet" and "Alloys").

Supplementary Material. The online version of this paper contains supplementary material (figures) available free of charge at the journal's Web site (www.lettersonmaterials.com).

\section{References}

1. J.M. D. Coey, M. Venkatesan, and P. Stamenov. J. Phys.: Condens. Matter. 28, 485001 (2016). DOI: 10.1088/0953-8984/28/48/485001

2. A.E. Ermakov, M.A. Uimin, A. V. Korolev, A.S. Volegov, I. V. Byzov, N. N. Shchegoleva, A.S. Minin. Fizika Tverdogo Tela, 59 (3), 458 (2017). (in Russian) [A.Е. Ермаков, М. А. Уймин, А. В. Королев, А. С. Волегов, И. В. Бызов, Н.Н. Щеголева, А.С. Минин. Физика твердого тела. 59 (3), 458 (2017).]

3. S. Bhattacharyya, A. Pucci, D. Zitoun, A. Gedanken.

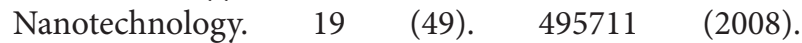
DOI: 10.1088/0957-4484/19/49/495711

4. S. Sharma, S. Chaudhary, S.C. Kashyap, S. K. Sharma. J. Appl. Phys. 109 (8), 083905 (2011). DOI: $10.1063 / 1.3567938$

5. S. A. Ahmed. J. Magn. Magn. Mater. 402 , 178 (2016). DOI: 10.1016/j.jmmm.2015.11.065

6. J. Jun, M. Dhayal, J.-H. Shin, J.-Ch. Kim, N. Getoff. Radiat. Phys. Chem. 75 (5) 583 (2006). DOI: 10.1016/j.radphyschem.2005.10.015

7. S. Yu. Sokovnin, M. E. Balezin. Rad. Phys. Chem. 144, 265 (2018). DOI: 10.1016/j.radphyschem.2017.08.023 